\title{
Intercropping Vicia sativa L. Improves the Moisture, Microbial Community, Enzyme Activity and Nutrient in Rhizosphere Soils of Young Kiwifruit Plants and Enhances Plant Growth
}

\author{
Qiuping Wang ${ }^{1,2}$, Cheng Zhang ${ }^{2}$, Jiaohong $\mathrm{Li}^{2}$, Xiaomao $\mathrm{Wu}^{2}$, Youhua Long ${ }^{2, *}$ and Yue $\mathrm{Su}^{1, *}$ \\ 1 Department of Food and Medicine, Guizhou Vocational College of Agriculture, Qingzhen 551400, China; \\ qpwang518@aliyun.com \\ 2 Research Center for Engineering Technology of Kiwifruit, Institute of Crop Protection, Teaching Experimental \\ Farm, College of Agriculture, Guizhou University, Guiyang 550025, China; \\ 2111816013@stmail.ujs.edu.cn (C.Z.); xhli@gzu.edu.cn (J.L.); xmwu@gzu.edu.cn (X.W.) \\ * Correspondence: yhlong3@gzu.edu.cn (Y.L.); suyue09136@163.com (Y.S.)
}

check for

updates

Citation: Wang, Q.; Zhang, C.; Li, J.; $\mathrm{Wu}, \mathrm{X}$.; Long, Y.; Su, Y. Intercropping Vicia sativa L. Improves the Moisture, Microbial Community, Enzyme Activity and Nutrient in Rhizosphere Soils of Young Kiwifruit Plants and Enhances Plant Growth. Horticulturae 2021, 7, 335. https://doi.org/ 10.3390/horticulturae7100335

Academic Editor: Xiaohong Yao

Received: 31 August 2021

Accepted: 17 September 2021

Published: 23 September 2021

Publisher's Note: MDPI stays neutral with regard to jurisdictional claims in published maps and institutional affiliations.

Copyright: (C) 2021 by the authors. Licensee MDPI, Basel, Switzerland. This article is an open access article distributed under the terms and conditions of the Creative Commons Attribution (CC BY) license (https:// creativecommons.org/licenses/by/ $4.0 /)$.

\begin{abstract}
Drought, low nutrition, and weeds have become the major limiting factors of young kiwifruit orchards. In this study, the effects of intercropping Vicia sativa L. on the moisture, microbe community, enzyme activity, and nutrients in rhizosphere soils of young kiwifruit plants and their growth were investigated. The results show that intercropping $V$. sativa could effectively enhance soil moisture by 1.39-1.47 folds compared with clean tillage. Moreover, intercropping $V$. sativa could significantly $(p<0.01)$ increase the microbial community, enzyme activity and nutrient of kiwifruit rhizosphere soils, and improve plant height, stem girth, leaf number, maximum leaf length, maximum leaf width, and chlorophyll content of young kiwifruit plants by $43.60 \%, 18.68 \%, 43.75 \%, 18.09 \%$, $21.15 \%$, and $67.57 \%$ compared to clean tillage, respectively. The moisture, microbial quantity, enzyme activity, and nutrients in rhizosphere soils of young kiwifruit plants exhibited good correlations with their plant height, stem girth, leaf number, maximum leaf length, maximum leaf width, and chlorophyll content. This study highlights that intercropping $V$. sativa in young kiwifruit orchard can be used as an effective, labor-saving, economical and sustainable practice to improve the moisture, microbial community, enzyme activity, and nutrient of soils, and enhance kiwifruit plant growth and control weeds.
\end{abstract}

Keywords: intercropping; kiwifruit; Vicia sativa L.; soil moisture and nutrient; soil microecology; enzyme activities; growth

\section{Introduction}

Kiwifruit (Actinidia), as an emerging, healthy, and economical fruit, rich in vitamin C with high nutritional and medicinal values. Recently, the kiwifruit industry has developed rapidly in the world, and its planting area and annual output have reached $381,800 \mathrm{hm}^{2}$ and 5.27 million tons by 2020, respectively. Especially in China, where the planting area and annual output of kiwifruit have reached $243,000 \mathrm{hm}^{2}$ and 2.5 million tons, respectively [1-3]. However, with the continuous expansion of kiwifruit cultivation, drought, low nutrition, and weeds have become the major limiting factors of young kiwifruit orchards, which often have a serious impact on the healthy growth of young kiwifruit plants. Although irrigation, fertilization, and mechanical or chemical weeding are the most effective practices to reduce the above adverse effects, they are high cost, and cause extensive labor consumption and low sustainability. Moreover, the negative effects of herbicide residues on environment, animal, and human health were reported [3-5]. Thus, it is urgent and essential to develop the green, effective, labor-saving, economic measures for the management of young kiwifruit orchard.

Intercropping, a widely used agricultural practice, can enhance the moisture, fertility, and structure of rhizosphere soils and weed suppression, thereby helping to improve soil 
quality, microflora, enzyme activity and so on, and promote the growth and development of plants and achieve a higher profitability [6-12]. Recently, orchard intercropping has been widely practiced, such as apple [13], grape [14], plum [15], olive [16], etc. Many reports have confirmed that orchard intercropping can enhance soil moisture and fertility, increase soil microbial biomass and enzyme activity, and improve soil structure [13-18]. Therefore, intercropping is widely used to efficiently utilize limited labor, diversify cropping systems, and promote sustainable agricultural development $[9,19]$. In our previous study, intercropping Reineckia carnea in an adult kiwifruit orchard could significantly increase the microorganism numbers, enzyme activities, moisture content of kiwifruit rhizosphere soils, and improve the yield and quality of kiwifruit fruits [20]. To date, however, little attention or documentation is available about intercropping plants in young kiwifruit orchards to improve soil quality and promote young kiwifruit growth.

$V$. sativa, in the subfamily Papilionoideae of Fabaceae, is a well-known species widely distributed in Central Asia, North Asia, Europe, and North America [21,22]. Due to its high protein content and great capacity for nitrogen fixation, it is considered as a superior forage and green fertilizer, which plays an energetic function in sustainable agriculture $[23,24]$. Wang et al. [25] reported that $V$. sativa and oat intercropping had greater forage yields and economic benefits compared with the corresponding monocultures in the agro-pastoral region of China, and a sowing ratio of oat at $50 \%$ was recommended. V. sativa is an annual leguminous herb, which is widely planted in Southwest and Northwest China, and the research on its intercropping with fruit trees is rarely reported. Moreover, kiwifruit producing areas in China are also mainly concentrated in the Southwest and Northwest. Thus, it is worth further studying whether intercropping V. sativa can be used as an effective and labor-saving measure to improve the rhizosphere soil quality of young kiwifruit plants and promote their growth.

In this study, intercropping $V$. sativa on the moisture, microbe community, enzyme activity, and nutrient of rhizosphere soils in young kiwifruit orchards was firstly evaluated. Moreover, the effects of intercropping $V$. sativa on the growth of young kiwifruit plants were investigated. This work could provide a green, effective, labor-saving, economical practice for improving rhizosphere soil quality of young kiwifruit plants and enhancing their growth.

\section{Materials and Methods}

\subsection{Mediums and Reagents}

Nutrient agar (NA, g/L): beef extract $(3 \mathrm{~g})$, peptone $(5 \mathrm{~g})$, glucose $(2.5 \mathrm{~g})$, agar $(18 \mathrm{~g})$, distilled water $(1 \mathrm{~L})$, $\mathrm{pH}$ 7.0. Gauze No. 1 agar $(\mathrm{GA}, \mathrm{g} / \mathrm{L})$ : soluble starch $(2 \mathrm{~g}), \mathrm{KNO}_{3}(0.1 \mathrm{~g})$, $\mathrm{K}_{2} \mathrm{HPO}_{4}(0.05 \mathrm{~g}) \mathrm{MgSO}_{4} \cdot 7 \mathrm{H}_{2} \mathrm{O}(0.05 \mathrm{~g}), \mathrm{NaCl}(0.05 \mathrm{~g}), \mathrm{FeSO}_{4} \cdot 7 \mathrm{H}_{2} \mathrm{O}(0.001 \mathrm{~g})$, agar (2 g), distilled water $(1 \mathrm{~L}), \mathrm{pH}$ 7.2 7.4. potato dextrose agar (PDA, g/L): potato $(200 \mathrm{~g})$, dextrose (20 g), agar (15 g), distilled water (1 L), pH value was natural. All mediums were sterilized at $121^{\circ} \mathrm{C}$ for $30 \mathrm{~min}$. All other chemicals had analytical purity.

\subsection{Experiment Design \\ 2.2.1. Study Site}

The field intercropping experiments were implemented in 2016-2017 in a young kiwifruit orchard at Xifeng country, Guizhou province, China $\left(27^{\circ} 04^{\prime}, 106^{\circ} 55^{\prime}\right)$. The cultivar was A. deliciosa cv. Guichang with 1-year-old grafted seedlings and the spacing of $3.0 \mathrm{~m} \times 3.0 \mathrm{~m}$. Male plants accounted for $1 / 9$ of the total plants. The mean altitude, annual rainfall, and temperature of the young kiwifruit orchard was about $1165 \mathrm{~m}$, $1203 \mathrm{~mm}$ and $12.5^{\circ} \mathrm{C}$, respectively. After the soil sample (0-60 $\mathrm{cm}$ in deep) was fully mixed, air-dried, ground and divided, and then its nutrient backgrounds were determined. Soils had $30.36 \mathrm{~g} / \mathrm{kg}$ of organic matter, $1.12 \mathrm{~g} / \mathrm{kg}$ of total nitrogen, $97.36 \mathrm{mg} / \mathrm{kg}$ of alkalihydrolyzable nitrogen, $14.95 \mathrm{mg} / \mathrm{kg}$ of available phosphorus, $1.16 \mathrm{mg} / \mathrm{kg}$ of available potassium, 6.53 of $\mathrm{pH}$ value. 


\subsubsection{Field Intercropping Experiment}

The experimental treatments included intercropping V. sativa and clean tillage. A total of six plots were arranged randomly with three replicates. Each plot contained ten trees, and the interior eight trees were used for evaluation. The intercropping of $V$. sativa in the young kiwifruit orchard follows the following steps: (1) After planting grafted seedlings of kiwifruit in February 2016, artificially mechanical weeding was carried out in young kiwifruit plots in September; (2) In October 2016, V. sativa seeds were sown in the intercropping plots at $1.5 \mathrm{~kg} / 667 \mathrm{~m}^{2}$, and then the soils of the intercropping plots waere ploughed by a rotary cultivator; (3) When fertilizing kiwifruit each time, the V. sativa seedlings in the tree tray were removed and mixed with tree tray soil and fertilizer, and then backfilled to cover the tree tray. The tree tray here refers to the soil that radiates $1.0 \mathrm{~m}$ from the center of the tree.

\subsection{Analytical Methods}

2.3.1. Determination of the Moisture Content, Microbe Numbers, Enzyme Activities and Nutrient of Kiwifruit Rhizosphere Soils

From 28 April in 2017, soil samples with a depth of 0-60 $\mathrm{cm}$ in the rhizosphere of kiwifruit were respectively collected by a 5-point sampling method at an interval of 30 days. Each soil sample was divided into three groups, soils of the first group were used to analyze soil moisture content, soils of the second group were used to determine soil microbe numbers, soils of the other group were air dried and used to determine soil enzyme activities. Soil moisture content was measured by the drying method. Soil microbe numbers were determined by the plate counting method [20,26]; NA medium was used for bacteria counting, GA medium was used for actinomycetes counting and PDA medium was used for fungi counting. The sucrase, urease, phosphatase, and catalase activities of soils were determined as described by Zhang et al [20]. Sucrase, urease, and phosphatase activities were determined by 3,5-dinitrosalicylic acid, indophenol blue and benzodisodium phosphate colorimetry, respectively. Catalase was checked by $0.1 \mathrm{~mol} \mathrm{~L}^{-1} \mathrm{KMnO}_{4}$ titration. Soil samples with a depth of $0-60 \mathrm{~cm}$ in the rhizosphere of kiwifruit were collected during the wilting period (15 October in 2017) of $V$. sativa to determine the nutrient content. The content of organic matter, total nitrogen, available phosphorus and available potassium of soils were determined as described by Long et al. [27].

\subsubsection{Determination of the Growth Parameters of Kiwifruit Plants}

On 26 August in 2017, the plant height, stem girth, number of leaves, maximum leaf length, and maximum leaf width of kiwifruit plants were determined by a meterstick. Moreover, chlorophyll content of kiwifruit leaves was measured by an acetone-ethanol $(v / v, 2: 1)$ extraction with colorimetry [28].

\subsection{Statistical Analyses}

Data were expressed as the means \pm standard deviations (SD) $(n=3)$. All analyses of variance and correlation were carried on SPSS 18.0 (SPSS Inc., Chicago, IL, USA). A one-way analysis of variance was used for determining the difference significances. A correlation matrix was based on Pearson's correlation coefficients. Origin 10.0 was used to produce the graphs.

\section{Results}

\subsection{Effects of Interplanting V. sativa on Moisture Content in Rhizosphere Soils of Young} Kiwifruit Plants

The effects of intercropping $V$. sativa on moisture content of rhizosphere soils in the young kiwifruit orchard are shown in Figure 1. Intercropping $V$. sativa significantly $(p<0.01)$ increased the moisture content of rhizosphere soils at different growth stages in young kiwifruit plants, which could enhance the moisture content of rhizosphere soils by 1.39-1.47 folds compared with clean tillage. These results indicate that intercropping 
$V$. sativa could effectively increase and maintain the moisture content in rhizosphere soils of young kiwifruit plants and improve their drought resistance and water retention.

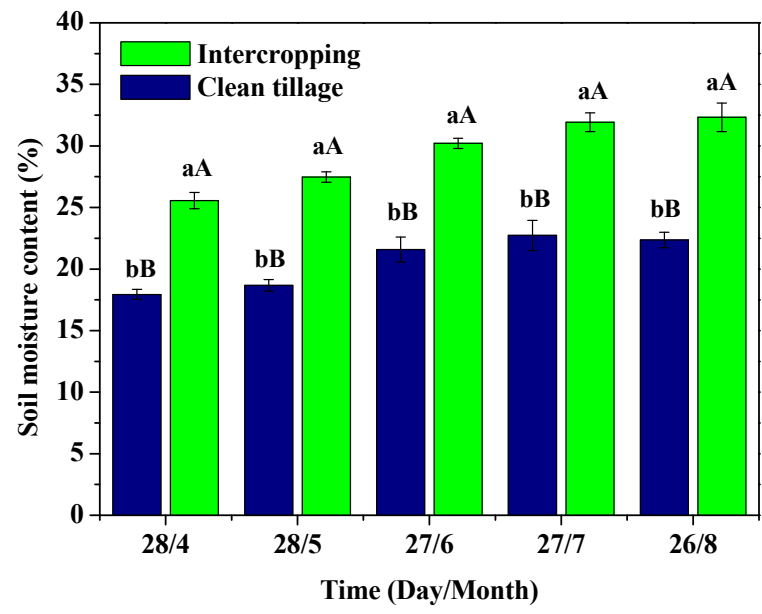

Figure 1. Effects of intercropping $V$. sativa on the moisture content of soils in young kiwifruit orchard. Values and error bars indicate the mean and SD of three replicates, respectively. Different small and capital letters in the same period indicate significant differences at $5 \%$ level $(p<0.05)$ and $1 \%$ level $(p<0.01)$ between intercropping and clean tillage, respectively.

\subsection{Effects of Interplanting $V$. sativa on Microbe Numbers in Rhizosphere Roils of Young Kiwifruit Plants}

The effects of intercropping $V$. sativa on the soil microbe numbers of young kiwifruit orchard are shown in Table 1. The microbe number in rhizosphere soils of young kiwifruit plants was dominated by bacteria under different planting patterns, followed by actinomycetes and fungi. The number of bacteria, actinomycetes, and fungi in kiwifruit rhizosphere soils gradually increased with the extension of the kiwifruit growth period. Intercropping $V$. sativa significantly $(p<0.01)$ increased the bacteria, actinomycetes, and fungi numbers of rhizosphere soils at different growth stages in young kiwifruit plants, which could enhance the bacteria, actinomycetes, and fungi numbers of rhizosphere soils by $1.53-2.74$ folds, $1.63-1.69$ folds and 1.62-2.47 folds compared with clean tillage, respectively. The findings here emphasize that intercropping $V$. sativa could significantly increase the soil microorganism amount in the young kiwifruit rhizosphere and improve the rhizosphere microecology of kiwifruit plants.

Table 1. Effects of intercropping $V$. sativa on soil microbe numbers of young kiwifruit orchard.

\begin{tabular}{|c|c|c|c|c|c|c|}
\hline \multirow{2}{*}{$\begin{array}{c}\text { Time } \\
\text { (Day/Month) }\end{array}$} & \multicolumn{2}{|c|}{ Bacteria $\left(\times 10^{8} \mathrm{cfu} \mathrm{g}^{-1}\right)$} & \multicolumn{2}{|c|}{ Actinomycetes $\left(\times 10^{7} \mathrm{cfu} \mathrm{g}^{-1}\right)$} & \multicolumn{2}{|c|}{ Fungi $\left(\times 10^{5} \mathrm{cfu} \mathrm{g}^{-1}\right)$} \\
\hline & Intercropping & Clean Tillage & Intercropping & Clean Tillage & Intercropping & Clean Tillage \\
\hline $28 / 4$ & $0.63 \pm 0.04^{\mathrm{aA}}$ & $0.23 \pm 0.04^{\mathrm{bB}}$ & $2.22 \pm 0.07^{\mathrm{aA}}$ & $1.33 \pm 0.04^{\mathrm{bB}}$ & $1.02 \pm 0.01^{\mathrm{aA}}$ & $0.63 \pm 0.01^{b B}$ \\
\hline $28 / 5$ & $0.71 \pm 0.01^{\mathrm{aA}}$ & $0.32 \pm 0.02^{b B}$ & $2.71 \pm 0.12^{\mathrm{aA}}$ & $1.63 \pm 0.03^{\mathrm{bB}}$ & $1.24 \pm 0.02^{\mathrm{aA}}$ & $0.65 \pm 0.03 \mathrm{bB}$ \\
\hline $27 / 6$ & $0.86 \pm 0.01^{\mathrm{aA}}$ & $0.52 \pm 0.02 \mathrm{bB}$ & $2.97 \pm 0.05^{\mathrm{aA}}$ & $1.83 \pm 0.03 \mathrm{bB}$ & $1.58 \pm 0.01^{\mathrm{aA}}$ & $0.73 \pm 0.01 \mathrm{bB}$ \\
\hline $27 / 7$ & $0.98 \pm 0.01^{\mathrm{aA}}$ & $0.63 \pm 0.01 \mathrm{bB}$ & $3.21 \pm 0.09 \mathrm{aA}$ & $1.90 \pm 0.01 \mathrm{bB}$ & $1.89 \pm 0.07^{\mathrm{aA}}$ & $0.78 \pm 0.01 \mathrm{bB}$ \\
\hline $26 / 8$ & $1.07 \pm 0.05^{\mathrm{aA}}$ & $0.70 \pm 0.01^{b B}$ & $3.52 \pm 0.01^{\mathrm{aA}}$ & $2.10 \pm 0.03^{b B}$ & $2.01 \pm 0.12^{\mathrm{aA}}$ & $0.81 \pm 0.03^{b B}$ \\
\hline
\end{tabular}

Values indicate the mean \pm SD of three replicates. Different small and capital letters in the same row indicate significant differences at $5 \%$ level $(p<0.05)$ and $1 \%$ level $(p<0.01)$ between intercropping and clean tillage, respectively.

\subsection{Effects of Interplanting V. sativa on Enzyme Activities in Rhizosphere Soils of Young Kiwifruit Plants}

The effects of intercropping $V$. sativa on sucrase, urease, phosphatase, and catalase activities in rhizosphere soils of young kiwifruit plants are shown in Figure 2. Sucrase activity of kiwifruit rhizosphere soils increased at first and then decreased during kiwifruit growth stages (Figure 2a). Intercropping $V$. sativa significantly $(p<0.01)$ increased su- 
crase activity of rhizosphere soils at different growth stages in young kiwifruit plants by 1.11-1.25 folds compared with clean tillage, which promoted the utilization of nutrients. Urease activity of kiwifruit rhizosphere soils in intercropping $V$. sativa gradually increased with the extension of kiwifruit growth period, while that in clean tillage increased at first and then decreased (Figure $2 b$ ). Intercropping $V$. sativa significantly $(p<0.01)$ increased urease activity of rhizosphere soils at different growth stages in young kiwifruit plants by 1.20-1.45 folds compared with clean tillage, which improved soil maturation and the transforming utilization of nitrogen. Phosphatase activity of kiwifruit rhizosphere soils in intercropping $V$. sativa also gradually increased, while that in clean tillage increased at first and then decreased (Figure 2c). Intercropping $V$. sativa significantly $(p<0.01)$ increased phosphatase activity in rhizosphere soils of young kiwifruit plants by 1.20-1.77 folds compared with clean tillage, which improved the transforming utilization of phosphorus. Catalase activity of kiwifruit rhizosphere soils increased gradually during kiwifruit growth stages (Figure 2d). Intercropping $V$. sativa significantly $(p<0.05)$ increased catalase activity in rhizosphere soils of young kiwifruit plants by 1.08-1.26 folds compared with clean tillage, which effectively reduced the damage of reactive oxygen species to kiwifruit root system and ensured its healthy growth.
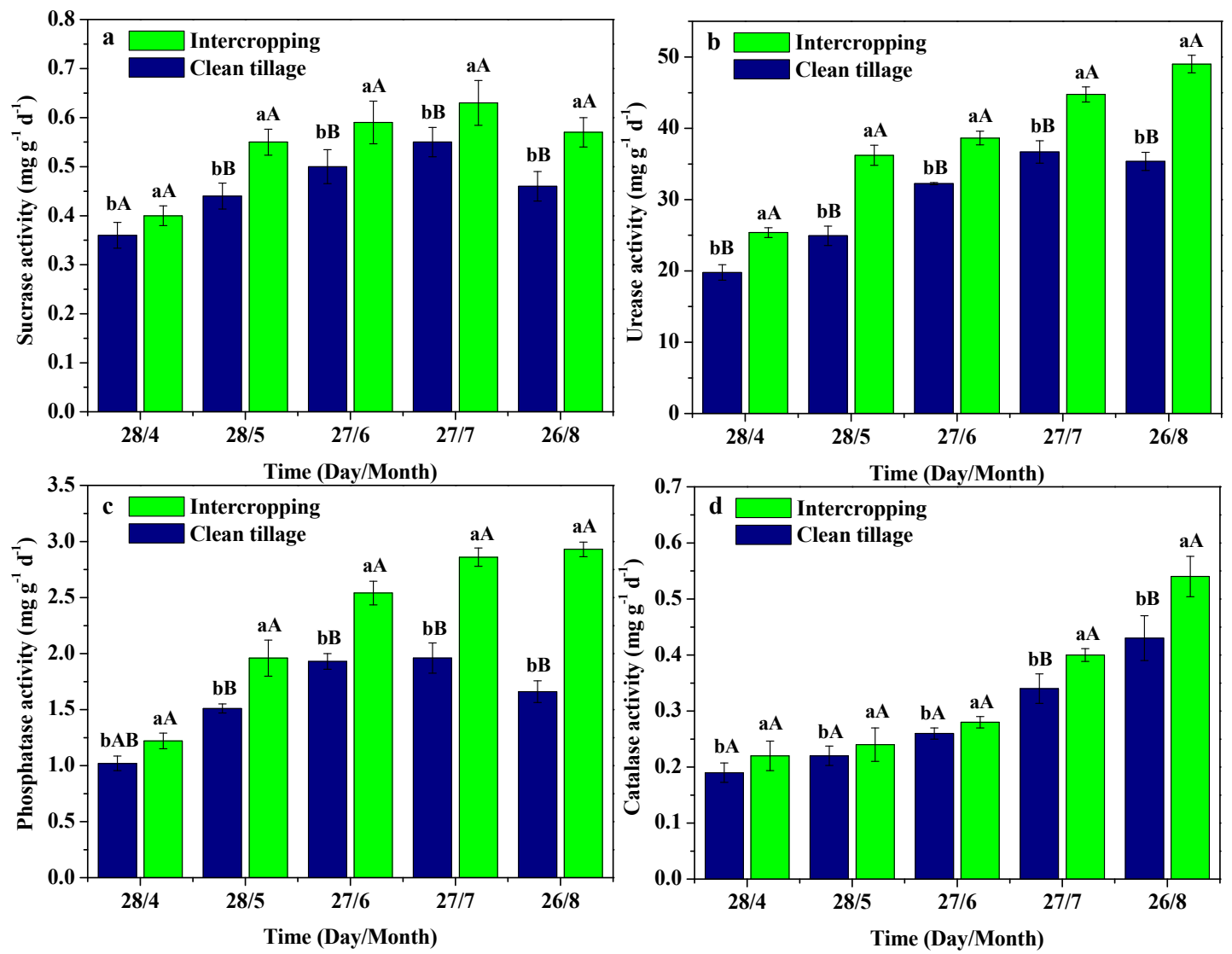

Figure 2. Effects of intercropping $V$. sativa on sucrase (a), urease (b), phosphatase (c), and catalase (d) activities of soils in young kiwifruit orchard. Values and error bars indicate the mean and SD of three replicates, respectively. Different small and capital letters in the same period indicate significant differences at $5 \%$ level $(p<0.05)$ and $1 \%$ level $(p<0.01)$ between intercropping and clean tillage, respectively.

\subsection{Effects of Interplanting V. sativa on Nutrients in Rhizosphere Soils of Young Kiwifruit Plants}

Table 2 displays the effects of intercropping $V$. sativa on soil nutrients of the young kiwifruit orchard. Intercropping $V$. sativa significantly $(p<0.01)$ enhanced the content of organic matter, total nitrogen, available phosphorus, and available potassium in rhizosphere soils of young kiwifruit plants, which effectively increased by $43.40 \%, 31.03 \%$, 
$39.19 \%$, and $20.33 \%$ compared to clean tillage, respectively. These results indicate that intercropping $V$. sativa could effectively enhance the accumulation of organic matter and the transforming utilization of nutrition in kiwifruit rhizosphere soils.

Table 2. Effects of intercropping $V$. sativa on soil nutrient of young kiwifruit orchard.

\begin{tabular}{|c|c|c|c|c|}
\hline Treatments & $\begin{array}{l}\text { Organic Matter } \\
\qquad\left(\mathrm{g} \mathrm{kg}^{-1}\right)\end{array}$ & $\begin{array}{l}\text { Total Nitrogen } \\
\qquad\left(\mathrm{g} \mathrm{kg}^{-1}\right)\end{array}$ & $\begin{array}{c}\text { Available } \\
\text { Phosphorus } \\
\left(\mathrm{mg} \mathrm{kg}^{-1}\right)\end{array}$ & $\begin{array}{l}\text { Available } \\
\text { Potassium } \\
\left(\mathrm{mg} \mathrm{kg}^{-1}\right)\end{array}$ \\
\hline Intercropping & $55.74 \pm 4.31^{\mathrm{aA}}$ & $1.52 \pm 0.04^{\mathrm{aA}}$ & $21.38 \pm 1.90^{\mathrm{aA}}$ & $1.48 \pm 0.05^{\mathrm{aA}}$ \\
\hline Clean tillage & $38.87 \pm 1.84^{b B}$ & $1.16 \pm 0.03^{b B}$ & $15.36 \pm 0.39 \mathrm{bB}$ & $1.23 \pm 0.04^{\mathrm{bB}}$ \\
\hline
\end{tabular}

Values indicate the mean \pm SD of three replicates. Different small and capital letters in the same rank indicate significant differences at $5 \%$ level $(p<0.05)$ and $1 \%$ level $(p<0.01)$, respectively.

\subsection{Effects of Interplanting V. sativa on Growth of Young Kiwifruit Plants}

The effects of intercropping $V$. sativa on growth of young kiwifruit plants are shown in Table 3. Intercropping $V$. sativa significantly $(p<0.01)$ improved plant height, stem girth, leaf number, maximum leaf length, maximum leaf width, and chlorophyll content of young kiwifruit plants, which effectively increased by $43.60 \%, 18.68 \%, 43.75 \%, 18.09 \%$, $21.15 \%$, and $67.57 \%$ compared to clean tillage, respectively. These results indicate that intercropping $V$. sativa could effectively promote the efficient use of water and nutrients, and thus apparently enhance growth of young kiwifruit plants.

Table 3. Effects of intercropping $V$. sativa on growth of kiwifruit plants.

\begin{tabular}{|c|c|c|c|c|c|c|}
\hline Treatments & $\begin{array}{l}\text { Plant Height } \\
\text { (cm) }\end{array}$ & $\begin{array}{l}\text { Stem Girth } \\
(\mathrm{cm})\end{array}$ & Leaf Number & $\begin{array}{l}\text { Maximum Leaf } \\
\text { Length }(\mathrm{cm})\end{array}$ & $\begin{array}{l}\text { Maximum Leaf } \\
\text { Width (cm) }\end{array}$ & $\begin{array}{c}\text { Chlorophyll } \\
\text { Content } \\
\left(\mathrm{mg} \mathrm{g}^{-1}\right)\end{array}$ \\
\hline Intercropping & $141.37 \pm 3.23^{\mathrm{aA}}$ & $3.05 \pm 0.10^{\mathrm{aA}}$ & $23.00 \pm 2.00^{\mathrm{aA}}$ & $15.21 \pm 0.25^{\mathrm{aA}}$ & $12.03 \pm 0.66^{\mathrm{aA}}$ & $0.62 \pm 0.03^{\mathrm{aA}}$ \\
\hline Clean tillage & $98.45 \pm 3.89 \mathrm{bB}$ & $2.57 \pm 0.11^{b B}$ & $16.00 \pm 1.00^{b B}$ & $12.88 \pm 0.69 \mathrm{bB}$ & $9.93 \pm 0.49 \mathrm{bB}$ & $0.37 \pm 0.03^{b B}$ \\
\hline
\end{tabular}

Values indicate the mean \pm SD of three replicates. Different small and capital letters in the same rank indicate significant differences at $5 \%$ level $(p<0.05)$ and $1 \%$ level $(p<0.01)$, respectively.

\subsection{Correlation of Soil Parameters and Growth Parameters}

The patterns of correlations between soil microbe numbers and nutrient parameters for both intercropped and clean tillage were similar. Bacterium, actinomycete, and fungus numbers in kiwifruit rhizosphere soils of intercropping V. sativa and clean tillage were positively correlated $(p<0.05$ or 0.01$)$ with the sucrase, urease, phosphatase, catalase activity and moisture content. Bacteria and actinomycetes, but not fungi were positively correlated with total nitrogen and available potassium $(p<0.05)$. Soil microbe numbers were not correlated with available phosphorus, except actinomycete numbers in clean tillage $(p<0.05)$. In both the intercropping and clean tillage treatments, plant growth parameters were positively correlated ( $p<0.05$ or 0.01 ) with organic matter, total nitrogen, and available phosphorus and potassium (Table 4). In contrast, selected plant growth parameters were correlated to some of the soil microbe numbers or nutrients in the intercropping treatment but not clean tillage. In the intercropping treatment but not clean tillage, both plant height and chlorophyll content were positively correlated with actinomycete numbers, sucrose, urease and phosphatase. The leaf number correlated with soil moisture content, sucrose, and urease, as well as chlorophyll content correlated with moisture content, actinomycete numbers, sucrase, urease, and phosphatase. 
Table 4. Correlations between soil parameters and growth parameters.

\begin{tabular}{|c|c|c|c|c|c|c|}
\hline Parameters & Plant Height & Stem Girth & Leaf Number & $\begin{array}{l}\text { Maximum Leaf } \\
\text { Length }\end{array}$ & $\begin{array}{c}\text { Maximum Leaf } \\
\text { Width }\end{array}$ & $\begin{array}{c}\text { Chlorophyll } \\
\text { Content }\end{array}$ \\
\hline & \multicolumn{6}{|c|}{ Intercropping } \\
\hline $\begin{array}{l}\text { Moisture } \\
\text { content }\end{array}$ & 0.488 & $0.556^{*}$ & $0.638 *$ & 0.275 & 0.209 & $0.521 *$ \\
\hline Bacteria & 0.411 & $0.629 *$ & 0.210 & $0.648 *$ & 0.644 * & 0.386 \\
\hline Actinomycetes & $0.649 *$ & $0.662 *$ & 0.474 & 0.412 & $0.672 *$ & $0.630 *$ \\
\hline Fungi & 0.428 & 0.445 & 0.235 & 0.175 & 0.459 & 0.404 \\
\hline Sucrase & 0.769 * & $0.779 *$ & 0.610 * & $0.549 *$ & $0.786^{*}$ & $0.753 *$ \\
\hline Urease & $0.679 *$ & $0.687^{*}$ & 0.547 * & 0.496 & 0.694 * & $0.667 *$ \\
\hline Phosphatase & $0.623 *$ & $0.639 *$ & 0.419 & 0.351 & 0.653 * & $0.600 *$ \\
\hline Catalase & 0.204 & 0.213 & 0.101 & 0.070 & 0.221 & 0.191 \\
\hline Organic matter & $0.998^{* *}$ & $1.000^{* *}$ & $0.901 * *$ & $0.850 *$ & $1.000^{* *}$ & $0.993 * *$ \\
\hline Total nitrogen & $0.989 * *$ & $0.983 * *$ & $0.971^{* *}$ & $0.940 * *$ & $0.976^{* *}$ & $0.996^{* *}$ \\
\hline $\begin{array}{c}\text { Available } \\
\text { phosphorus }\end{array}$ & $0.852 *$ & $0.831 *$ & $0.987^{* *}$ & $0.998 * *$ & 0.810 * & $0.879 *$ \\
\hline \multirow[t]{2}{*}{$\begin{array}{l}\text { Available } \\
\text { potassium }\end{array}$} & $0.980 * *$ & $0.972 * *$ & $0.982 * *$ & $0.957^{* *}$ & $0.963 * *$ & $0.990 * *$ \\
\hline & \multicolumn{6}{|c|}{ Clean tillage } \\
\hline $\begin{array}{l}\text { Moisture } \\
\text { content }\end{array}$ & 0.132 & 0.474 & 0.4 & 0.132 & 0.474 & 0.446 \\
\hline Bacteria & 0.385 & $0.661 *$ & 0.385 & $0.661 *$ & $0.643 *$ & 0.385 \\
\hline Actinomycetes & 0.477 & $0.747 *$ & 0.477 & $0.747 *$ & 0.731 * & 0.477 \\
\hline Fungi & 0.148 & 0.447 & 0.148 & 0.447 & 0.423 & 0.148 \\
\hline Sucrase & 0.399 & $0.647 *$ & 0.399 & $0.646^{*}$ & 0.631 * & 0.399 \\
\hline Urease & 0.28 & $0.569 *$ & 0.28 & 0.569 * & 0.548 * & 0.280 \\
\hline Phosphatase & 0.454 & $0.765 *$ & 0.454 & $0.765 *$ & 0.745 * & 0.454 \\
\hline Catalase & 0.188 & 0.373 & 0.188 & 0.373 & 0.360 & 0.188 \\
\hline Organic matter & $0.938^{* *}$ & $0.977^{* *}$ & $0.938^{* *}$ & $0.978^{* *}$ & $0.987^{* *}$ & $0.938^{* *}$ \\
\hline Total nitrogen & $0.866^{*}$ & $0.999 * *$ & $0.866^{*}$ & $0.999 * *$ & $1.000^{* *}$ & $0.866^{*}$ \\
\hline $\begin{array}{c}\text { Available } \\
\text { phosphorus }\end{array}$ & $0.998^{* *}$ & 0.877 * & $0.998^{* *}$ & $0.878^{*}$ & $0.902 * *$ & $0.998^{* *}$ \\
\hline $\begin{array}{l}\text { Available } \\
\text { potassium }\end{array}$ & $0.803 *$ & $0.998^{* *}$ & 0.803 * & $0.997 * *$ & $0.992 * *$ & $0.803 *$ \\
\hline
\end{tabular}

Note: ${ }^{* *}$ Correlation is significant at the 0.01 level, ${ }^{*}$ Correlation is significant at the 0.05 level (2-tailed).

\section{Discussion}

\subsection{Soil Moisture}

Soil evaporation accounts for a large proportion of the total water consumption by cropping systems, and mulching practice plays an important role in reducing it $[29,30]$. Maize-pea and wheat-maize intercropping could reduce soil evaporation by $15-30 \%$ and $17.7-31.9 \%$, respectively [31,32]. Straw mulching in intercropping significantly reduced soil evaporation by $5.8-13.1 \%$ compared to conventional tillage [33]. The results here show that intercropping $V$. sativa could effectively increase and maintain the moisture content of rhizosphere soils at different growth stages in young kiwifruit plants. The phenological periods of $V$. sativa can be roughly divided into the sowing period (September to October), the seedling period (October to November), the flowering period (May to June) and the dry yellow period (August to September), while that of young kiwifruit plants include the budding period (February to March), the branch and leaf growth period (April to September) and the withering period (November to December). In the whole growth period of young kiwifruit plants, intercropping $V$. sativa mulched soils in whole orchard, which effectively reduced soil evaporation and improved water retention of soils. 


\subsection{Soil Microbial Community}

Soil moisture strongly affects the physical and chemical properties of rhizosphere soils and life activities of plant roots. Many studies have shown that orchard intercropping can improve the species and quantity of soil microorganisms, which is closely related to the symbiotic system formed between intercropping plants and fruit trees $[19,20]$. This system regulates the physiological activities of roots, promotes the actions of root exudates and decomposition substances, and the activities of rhizosphere soil microorganisms, so that the soil microbial quantity is at a high level $[34,35]$. The present results show that intercropping $V$. sativa could significantly increase soil microorganism amount in young kiwifruit rhizosphere, and soil moisture was significantly positive correlated with its bacteria, actinomycetes, and fungi numbers. This may be related to the increase of secretions and decomposers in kiwifruit rhizosphere soils after intercropping $V$. sativa, which provide rich nutrition for soil microorganisms [36,37]. Moreover, intercropping V. sativa can also increase soil moisture in kiwifruit rhizospheres which provides a suitable growth environment for soil microorganisms. These favorable conditions promoted the movement, colonization and propagation of soil microorganisms into the kiwifruit rhizosphere, and increased soil microbial community diversity.

\subsection{Soil Enzyme Activities}

Soil enzyme activity is affected by soil temperature, moisture, microbes, organic carbon, and other factors. Intercropping $V$. sativa significantly enhanced sucrase, urease, phosphatase, and catalase activities of rhizosphere soils at different growth stages in young kiwifruit plants, which is consistent with the results of intercropping plants to improve the enzyme activity in rhizosphere soils of apple, grape, plum, olive and kiwifruit [13-16,20]. Soil enzymes are mainly derived from soil microbial metabolites and plant root exudates, and the species and quantity of soil microbial determine soil enzymes, so that there are certain correlations between the microbe quantity, enzyme activity, moisture and nutrient of rhizosphere soils $[38,39]$. The results in the present study indicate that soil moisture and microbial quantity in kiwifruit rhizosphere soils were positively correlated with its sucrase, urease, phosphatase, and catalase activities. Good moisture conditions promote the propagation of soil microorganisms and the life activities of kiwifruit roots, thereby contributing to enhance soil enzyme activity in young kiwifruit rhizosphere.

\subsection{Soil Nutrient}

Soil sucrase, urease, phosphatase, and catalase activities play important roles in the transformation and utilization of organic matter, nitrogen, phosphorus, as well as the removal of reactive oxygen species, respectively $[20,39,40]$. In this study, intercropping $V$. sativa significantly enhanced the content of organic matter, total nitrogen, available phosphorus, and available potassium of rhizosphere soils in young kiwifruit plants, which effectively increased by $43.40 \%, 31.03 \%, 39.19 \%$ and $20.33 \%$ compared to clean tillage, respectively. The correlation analysis shows that organic matter, total nitrogen and available potassium in kiwifruit rhizosphere soils were positively correlated with their bacterium number, actinomycete number, sucrase activity, urease activity and phosphatase activity, and available phosphorus was positively correlated with phosphatase activity. As a superior green fertilizer, the decomposition of $V$. sativa can increase soil organic matter, and it also has a great capacity for nitrogen fixation $[23,24]$. Moreover, intercropping $V$. sativa could improve and maintain soil moisture, enrich soil microbial community, as well as enhance soil enzyme activities related to nutrient utilization. These favorable factors effectively enhanced the accumulation of organic matter and the transforming utilization of nutrition in kiwifruit rhizosphere soils.

\subsection{Plant Growth and Weeds Control}

Soil microbes and enzymes are important components of the rhizosphere soil ecosystem, which participate in various biochemical reactions such as material metabolism, 
nutrient transformation, and organic matter decomposition, and promote the balanced supply of moisture and nutrients in rhizosphere soils [38]. The adequate supply of moisture and nutrients is a prerequisite for the vigorous growth of plants. The results indicate that intercropping $V$. sativa not only increased moisture and nutrients of kiwifruit rhizosphere soils, but also effectively promoted plant height, stem girth, leaf number, maximum leaf length, maximum leaf width, and chlorophyll content of young kiwifruit plants. The correlation analysis also shows that the growth parameters of young kiwifruit plants were positively correlated with the moisture, microbe quantity, enzyme activity and nutrients of kiwifruit rhizosphere soils. These findings here emphasize that intercropping $V$. sativa enhanced the moisture, microbial community, enzyme activity, and fertility of rhizosphere soils, and effectively promoted the growth and development of young kiwifruit plants.

Weeds are one of the major limitations in the growth and development of young kiwifruit plants. Intercropping has proven to achieve weed control through competing for resources with weeds and intercrops may secrete allelochemicals to the detriment weed growth [41-43]. However, we did not assess the presence of weeds in our study, so this potential benefit of intercropping warrants further research. This study highlights that the intercropping $V$. sativa is an effective, labor-saving, economical and sustainable approach for improving the moisture, microbial community, enzyme activity and nutrients of young kiwifruit rhizosphere soils, and enhancing the growth of young kiwifruit plants.

\section{Conclusions}

In conclusion, intercropping $V$. sativa could significantly $(p<0.01)$ increase the moisture, microbial community, enzyme activity, and nutrients of young kiwifruit rhizosphere soils. Moreover, intercropping V. sativa reliably improved the growth of young kiwifruit plants. This work highlights that intercropping $V$. sativa can effectively enhance the quality of rhizosphere soils in young kiwifruit plants and improve their growth and development.

Author Contributions: Y.L. constructed the project; Y.L., Y.S. and Q.W. designed the experiments; Q.W. and C.Z. performed the experiments; Q.W., J.L. and X.W. analyzed the data; Q.W. and C.Z. wrote the paper. All authors have read and agreed to the published version of the manuscript.

Funding: This work was supported by the Support Plan Projects of Science and Technology Department of Guizhou Province (No. (2021) YB237, (2020)1Y016, (2019)2703, (2017)2566-1, [2017]2571), the Support Plan Projects of Guiyang City (No. (2017)26-1), the Science and Technology Innovation Talent Project of Guizhou Province [No. (2016)5672], and the Cultivation Program of Guizhou University [No. (2019)09].

Data Availability Statement: The datasets during or analyzed during the current study available from the corresponding author on reasonable request.

Conflicts of Interest: We declare that we do not have any commercial or associative interest that represents a conflict of interest in connection with the work submitted.

\section{References}

1. Hu, H.; Zhou, H.; Li, P. Lacquer wax coating improves the sensory and quality attributes of kiwifruit during ambient storage. Sci. Hortic. 2019, 244, 31-41. [CrossRef]

2. Zhang, M.; Xu, L.; Zhang, L.; Guo, Y.; Qi, X.; He, L. Effects of quercetin on postharvest blue mold control in kiwifruit. Sci. Hortic. 2018, 228, 18-25. [CrossRef]

3. Wang, Q.; Zhang, C.; Long, Y.; Wu, X.; Su, Y.; Lei, Y.; Ai, Q. Bioactivity and control efficacy of the novel antibiotic tetramycin against various kiwifruit diseases. Antibiotics 2021, 10, 289. [CrossRef] [PubMed]

4. Nedunchezhiyan, M.; Ravindran, C.S.; Velumani, R. Weed management in root and tuber crops in India: Critical analysis. J. Root Crop. 2013, 39, 13e20.

5. Brooker, R.W.; Bennett, A.E.; Cong, W.-F.; Daniell, T.J.; George, T.S.; Hallett, P.; Hawes, C.; Iannetta, P.P.M.; Jones, H.G.; Karley, A.J.; et al. Improving intercropping: A synthesis of research in agronomy, plant physiology and ecology. New Phytol. 2014, 206, 107-117. [CrossRef] [PubMed]

6. Martin-Guay, M.-O.; Paquette, A.; Dupras, J.; Rivest, D. The new green revolution: Sustainable intensification of agriculture by intercropping. Sci. Total. Environ. 2017, 615, 767-772. [CrossRef] 
7. Weerarathne, L.; Marambe, B.; Chauhan, B.S. Intercropping as an effective component of integrated weed management in tropical root and tuber crops: A review. Crop. Prot. 2017, 95, 89-100. [CrossRef]

8. Weerarathne, L.; Marambe, B.; Chauhan, B. Does intercropping play a role in alleviating weeds in cassava as a non-chemical tool of weed management?-A review. Crop. Prot. 2017, 95, 81-88. [CrossRef]

9. Yin, W.; Chai, Q.; Zhao, C.; Yu, A.; Fan, Z.; Hu, F.; Fan, H.; Guo, Y.; Coulter, J.A. Water utilization in intercropping: A review. Agric. Water Manag. 2020, 241, 106335. [CrossRef]

10. Bančič, J.; Werner, C.R.; Gaynor, R.C.; Gorjanc, G.; Odeny, D.A.; Ojulong, H.F.; Dawson, I.K.; Hoad, S.P.; Hickey, J.M. Modeling Illustrates that genomic selection provides new opportunities for intercrop breeding. Front. Plant Sci. 2021, 12, 605172. [CrossRef]

11. Khanal, U.; Stott, K.; Armstrong, R.; Nuttall, J.; Henry, F.; Christy, B.; Mitchell, M.; Riffkin, P.; Wallace, A.; McCaskill, M.; et al. Intercropping—evaluating the advantages to broadacre systems. Agriculture 2021, 11, 453. [CrossRef]

12. Weih, M.; Karley, A.; Newton, A.; Kiær, L.; Scherber, C.; Rubiales, D.; Adam, E.; Ajal, J.; Brandmeier, J.; Pappagallo, S.; et al. Grain yield stability of cereal-legume intercrops is greater than sole crops in more productive conditions. Agriculture 2021, 11, 255. [CrossRef]

13. Yin, R.J.; Wen, X.X.; Liao, Y.C.; Huang, J.H.; Gao, M.S. Effect of tillage and mulching on enzyme activities of apple orchard soil. Acta Hortic. Sin. 2009, 36, 717-722. (In Chinese)

14. Xi, Z.M.; Yue, T.X.; Zhang, J.; Cheng, J.M.; Li, H. Relationship between soil biological characteristics and nutrient content under intercropping system of vineyard in northwestern semiarid area. Sci. Agric. Sin. 2011, 44, 2310-2317. (In Chinese) [CrossRef]

15. Xu, X.; Zhang, J.; Zhang, M.; Liao, E.H. Relationship between biological factors and soil nutrients in artificial fruit-grass ecosystem. J. Soil Water Conserv. 2005, 19, 178-181. (In Chinese) [CrossRef]

16. Moreno, B.; Garcia-Rodriguez, S.; Cañizares, R.; Castro, J.; Benítez, E. Rainfed olive farming in South-Eastern Spain: Long-term effect of soil management on biological indicators of soil quality. Agric. Ecosyst. Environ. 2009, 131, 333-339. [CrossRef]

17. Floch, C.; Capowiez, Y.; Criquet, S. Enzyme activities in apple orchard agroecosystems: How are they affected by management strategy and soil properties. Soil Biol. Biochem. 2009, 41, 61-68. [CrossRef]

18. Yin, W.; Yu, A.; Guo, Y.; Wang, Y.; Zhao, C.; Fan, Z.; Falong, H.; Chai, Q. Straw retention and plastic mulching enhance water use via synergistic regulation of water competition and compensation in wheat-maize intercropping systems. Field Crop. Res. 2018, 229, 78-94. [CrossRef]

19. Ouma, G.; Jeruto, P. Sustainable horticultural crop production through intercropping: The case of fruits and vegetable crops: A review. Agric. Biol. J. N. Am. 2010, 1, 1098-1105. [CrossRef]

20. Zhang, C.; Wang, Q.P.; Zhou, K.T.; Wu, X.M.; Long, Y.H.; Li, J.H.; Yin, X.Y. Effects of intercropping Reineckia carnea on soil enzyme activity and kiwifruit fruit yield, quality in kiwifruit orchard. Sci. Agric. Sin. 2018, 51, 1556-1567. (In Chinese) [CrossRef]

21. Huang, Y.; Zhang, Z.; Nan, Z.; Unkovich, M.; Coulter, J.A. Effects of cultivar and growing degree day accumulations on forage partitioning and nutritive value of common vetch (Vicia sativa L.) on the Tibetan plateau. J. Sci. Food Agric. 2020, 101, $3749-3757$. [CrossRef]

22. Greveniotis, V.; Bouloumpasi, E.; Zotis, S.; Korkovelos, A.; Ipsilandis, C. Assessment of interactions between yield components of common vetch cultivars in both conventional and low-input cultivation systems. Agriculture 2021, 11, 369. [CrossRef]

23. Huang, Y.; Gao, X.L.; Nan, Z.B.; Zhang, Z.X. Potential value of the common vetch (Vicia sativa L.) as an animal feedstuff: A review. J. Anim. Physiol. Anim. Nutr. 2017, 101, 807-823. [CrossRef] [PubMed]

24. De la Rosa, L.; López-Román, M.I.; González, J.M.; Zambrana, E.; Marcos-Prado, T.; Ramírez-Parra, E. Common vetch, valuable germplasm for resilient agriculture: Genetic characterization and Spanish core collection development. Front. Plant Sci. 2021, 12, 617873. [CrossRef] [PubMed]

25. Wang, S.; Chen, G.; Yang, Y.; Zeng, Z.; Hu, Y.; Zang, H. Sowing ratio determines forage yields and economic benefits of oat and common vetch intercropping. Agron. J. 2021, 113, 2607-2617. [CrossRef]

26. Hu, K.H. Microbiology Experiment; China Forestry Press: Beijing, China, 2004; pp. 35-38. (In Chinese)

27. Long, Y.H.; Yin, X.H.; Wang, M.; Wu, X.M.; Li, R.Y.; Tian, X.L.; Li, M. Effects of sulfur on kiwifruit canker caused by Pseudomonas syringae pv. Actinidae. Bangladesh J. Bot. 2017, 46, 1183-1192.

28. Zhang, C.; Long, Y.-H.; Wang, Q.-P.; Li, J.-H.; Wu, X.-M.; Li, M. The effect of preharvest $28.6 \%$ chitosan composite film sprays for controlling the soft rot on kiwifruit. Hortic. Sci. 2019, 46, 180-194. [CrossRef]

29. Yin, W.; Fan, Z.; Hu, F.; Yu, A.; Zhao, C.; Chai, Q.; Coulter, J.A. Innovation in alternate mulch with straw and plastic management bolsters yield and water use efficiency in wheat-maize intercropping in arid conditions. Sci. Rep. 2019, 9, 6364. [CrossRef] [PubMed]

30. Kandel, H.; Samarappuli, D.; Johnson, K.; Berti, M. Soybean relative maturity, not row spacing, affected interseeded cover crops biomass. Agriculture 2021, 11, 441. [CrossRef]

31. Teng, Y.-Y.; Zhao, C.; Chai, Q.; Hu, F.-L.; Feng, F.-X. Effects of postponing nitrogen topdressing on water use characteristics of maize-pea intercropping system. Acta Agron. Sin. 2016, 42, 446-455. [CrossRef]

32. Yang, C.; Huang, G.; Chai, Q.; Luo, Z. Water use and yield of wheat/maize intercropping under alternate irrigation in the oasis field of northwest China. Field Crop. Res. 2011, 124, 426-432. [CrossRef]

33. Fan, Z.; Chai, Q.; Huang, G.; Yu, A.; Huang, P.; Yang, C.; Tao, Z.; Liu, H. Yield and water consumption characteristics of wheat/maize intercropping with reduced tillage in an Oasis region. Eur. J. Agron. 2013, 45, 52-58. [CrossRef] 
34. Vepsäläinen, M.; Erkomaa, K.; Kukkonen, S.; Vestberg, M.; Wallenius, K.; Niemi, R.M. The impact of crop plant cultivation and peat amendment on soil microbial activity and structure. Plant Soil 2004, 264, 273-286. [CrossRef]

35. Niemi, R.; Vepsäläinen, M.; Wallenius, K.; Simpanen, S.; Alakukku, L.; Pietola, L. Temporal and soil depth-related variation in soil enzyme activities and in root growth of red clover (Trifolium pratense) and timothy (Phleum pratense) in the field. Appl. Soil Ecol. 2005, 30, 113-125. [CrossRef]

36. Sosnoskie, L.M.; Cardina, J. Laboratory methods for breaking dormancy in garlic mustard (Alliaria petiolata) seeds. Invasive Plant Sci. Manag. 2008, 82, 122-130. [CrossRef]

37. Zhao, J.; Zeng, Z.; He, X.; Chen, H.; Wang, K. Effects of monoculture and mixed culture of grass and legume forage species on soil microbial community structure under different levels of nitrogen fertilization. Eur. J. Soil Biol. 2015, 68, 61-68. [CrossRef]

38. Richardson, A.E.; Barea, J.M.; McNeill, A.M.; Prigent-Combaret, C. Acquisition of phosphorus and nitrogen in the rhizosphere and plant growth promotion by microorganisms. Plant Soil 2009, 321, 305-339. [CrossRef]

39. Zhao, X.L.; Liu, X.H.; He, J.Z.; Wan, C.X.; Gong, M.F.; Zhang, L.L. Effects of cotton root exudates on available soil nutrition, enzyme activity and microorganism quantity. Acta Bot. Boreali-Occident. Sin. 2009, 29, 1426-1431. (In Chinese)

40. Zhang, C.; Long, Y.; Li, J.; Li, M.; Xing, D.; An, H.; Wu, X.; Wu, Y. A chitosan composite film sprayed before pathogen infection effectively controls postharvest soft rot in kiwifruit. Agronomy 2020, 10, 265. [CrossRef]

41. Arora, K.; Batish, D.R.; Singh, H.P.; Kohli, R.K. Allelopathic potential of the essential oil of wild marigold (Tagetes minuta L.) against some invasive weeds. J. Environ. Agric. Sci. 2015, 3, 56-60.

42. Seran, T.H.; Brintha, I. Review on maize based intercropping. J. Agron. 2010, 9, 135-145. [CrossRef]

43. Korieocha, D.S. Weed control in national root crops research institute Umudike and its recommendation. Res. J. Agric. Environ. Manag. 2014, 4, 1-4. 